Available online at www.banglajol.info

Bangladesh J. Sci. Ind. Res. 47(3), 279-286, 2012

\section{BANGLADESH JOURNAL OF SCIENTIFIC AND \\ INDUSTRIAL RESEARCH \\ E-mail: bjsir07@gmail.com}

\title{
Surface water quality around DEPZ industrial area, Savar, Dhaka
}

\author{
H. Momtaz ${ }^{\mathrm{a}}$, F. Alam ${ }^{\mathrm{b}}$, M. A. Ahsan**, M. A. Akbor ${ }^{\mathrm{a}}$ and M. M. Rashid ${ }^{\mathrm{a}}$ \\ ${ }^{a}$ Analytical Research Division, BCSIR Laboratories, Dhaka ${ }^{b}$ The Science Prove International, Tejgaon, Dhaka
}

\begin{abstract}
Some important physico-chemical properties of surface water around DEPZ industrial area, Savar were studied to evaluate the water quality. Seven water samples were collected from major waterbodies of DEPZ industrial area. The value of Physico-chemical parameter such as Temperature (57-24 $\left.{ }^{\circ} \mathrm{C}\right), \mathrm{pH}(12.45-7.58), \mathrm{EC}(12400-2060 \mu \mathrm{s} / \mathrm{cm}), \mathrm{BOD}_{5}(895-63.19 \mathrm{mg} / \mathrm{L}), \mathrm{TSS}(2170-435 \mathrm{mg} / \mathrm{L})$, TDS (6840-1036 $\mathrm{mg} / \mathrm{L})$, Turbidity (89.55-32.16 mg/L) and Salinity (7.1-1.0 ppt) were highest in the point source (W1) and began to decline as the waste dispersed through the nearby waterbodies $\left(\mathrm{W}_{2}-\mathrm{W}_{7}\right)$. The result revealed that all the chemical constituents, except a few, were beyond the recommended limit for various uses. The lowest content of DO $(0.10 \mathrm{mg} / \mathrm{L})$ and highest content of $\mathrm{BOD}_{5}(895 \mathrm{mg} / \mathrm{L})$ in point source waterbody indicate that the industries were releasing large amount of oxygen demanding organic wastes which subsequently affected all the studied waterbody. Among metal content of the study area, the value of Fe (1.331-0.443 mg/L), Zn (0.308-0.134 mg/L), Cu (0.244 0.127 mg/L) and $\mathrm{Cr}(0.615-0.055 \mathrm{mg} / \mathrm{L})$ were gradually decreased from point source to the remote area. Point source $\left(\mathrm{W}_{1}\right)$ waterbody had the highest concentration of $\mathrm{Cr}(0.615 \mathrm{mg} / \mathrm{L})$ which exceeded the safe limit for industrial wastewater. This may be due to various chrome agent used in dyeing purposes. Anionic parameters like $\mathrm{F}^{-}$and $\mathrm{PO}_{4}{ }^{3-}$ were at intolerable limit in some waterbody. The coefficient of correlation analysis among physicochemical properties indicated that all the parameters had significant contribution to pollute the water. The correlation between $\mathrm{DO}$ and $\mathrm{pH}$ was strongly negative $\left(\mathrm{r}=-0.995^{* *}\right)$. Fe showed positive significant correlation with $\mathrm{Zn}, \mathrm{Cu}$ and $\mathrm{Cr}$. There was a significant positive interaction of $\mathrm{PO}_{4}{ }^{3-}$ with $\mathrm{Cl}^{-}$and $\mathrm{NO}^{3-}$ in case of water quality deterioration. The above findings showed that the surface water around DEPZ industrial area was highly polluted by the industrial activities and was harmful for life.
\end{abstract}

Keywords: Industrial effluents, Surface water quality, DEPZ Industrial area.

\section{Introduction}

Surface water systems of Bangladesh at present time are polluted by various ways (Islam, 2009). The sources of surface water pollution are mainly from agricultural, industrial and domestic wastes (Dara, 2002 and De, 2000). Industrial pollution is one of the major problems that Bangladesh facing to a greater extent. They are one of the largest water users and polluters (Nemerow, 1978). The careless disposal of industrial effluents and other wastes may contribute greatly to the poor quality of the water (Chindah et al, 2004). The quality of water interferes with the aesthetic and economic pursuits of water bodies by affecting fish and other aquatic life (Islam et al, 2009).

The textile dyeing industries of Savar generate large amount of effluents, sewage sludge and solid waste materials everyday which are being directly discharged into the surrounding channel, agricultural field and in the nearby surface water bodies. Textile and dyeing industrial effluents offer the alteration of physical, chemical and biological properties of aquatic environment by counting change in temperature, odor, noise, turbidity and to the original properties that is harmful to public health, livestock, wildlife, fish and other biodiversity (Haque et al., 2002).

The study area located at Dhamsona union, Savar thana in the district of Dhaka. The selected sites situated from the effluent discharging point (back side) of the DEPZ to the Bangshi River in which effluents are finally mixed. This area contains different polluted waterbodies which are joined by channels and the effluent finally polluted the Bangshi River. So the contamination of these aquatic systems brings serious threat to the overall epidemic and socio-economic pattern of the neighboring area and no systemic data was found about the water quality of DEPZ industrial area. So, proper analy- 
sis is needed to assess the pollution level and also for the protection of environment and natural resources.

The present research work will ventilate more information about the physicochemical, anionic parameters and heavy metal contents in order to characterize the surface water quality surrounding the DEPZ industrial region which can be used as benchmark data for future surface water resource planning and management of Savar industrial area. Such information can also provide valuable information for the authorities to take proper action in preventing pollution of the area.

\section{Materials and Methods}

Water samples were collected from seven major waterbodies around the DEPZ industrial area during the dry period of July 2010. Among the seven waterbodies, $\mathrm{W}_{1}$ $\left(23^{\circ} 56^{\prime} 53.01 " \mathrm{~N}, 90^{\circ} 15^{\prime} 38.12^{\prime \prime} \mathrm{E}\right)$ denotes the point source waterbody. $\mathrm{W}_{2} \quad\left(23^{\circ} 57^{\prime} 1.52^{\prime \prime} \mathrm{N}, \quad 90^{\circ} 15^{\prime} 28.31 " \mathrm{E}\right), \quad \mathrm{W}_{3}$ $\left(23^{\circ} 57^{\prime} 2.01 " \mathrm{~N}, \quad 90^{\circ} 15^{\prime} 16.03^{\prime \prime} \mathrm{E}\right), \quad \mathrm{W}_{4} \quad\left(23^{\circ} 56^{\prime} 54.86^{\prime \prime} \mathrm{N}\right.$ $\left.90^{\circ} 14^{\prime} 59.64^{\prime \prime} \mathrm{E}\right), \quad \mathrm{W}_{5}\left(23^{\circ} 56^{\prime} 48.99^{\prime \prime} \mathrm{N}, 90^{\circ} 14^{\prime} 41.60^{\prime \prime} \mathrm{E}\right), \mathrm{W}_{6}$ $\left(23^{\circ} 56^{\prime} 50.19^{\prime \prime} \mathrm{N}, 90^{\circ} 14^{\prime} 23.48^{\prime \prime} \mathrm{E}\right)$, and $\mathrm{W}_{7}\left(23^{\circ} 56^{\prime} 39.69^{\prime \prime} \mathrm{N}\right.$, $\left.90^{\circ} 14^{\prime} 9.22^{\prime \prime} \mathrm{E}\right)$ denote water bodies with increasing distance of about half kilometer from the source and nearby waterbody respectively (Figure 1 ). $\mathrm{W}_{6}$ and $\mathrm{W}_{7}$ are the waterbody close to Bangshi River in which wastewater from all sites finally mixed. A sample size of half litre was collected form four station of each waterbody to afford a representative sample. The sampling was done very carefully using spot sampling techniques (Gupta, 2005). The high density PVC bottles were used for sampling. They were thoroughly cleaned by rinsing with $8 \mathrm{~N} \mathrm{HNO}_{3}$ and deionized water followed by repeated washing with water samples so as to avoid contamination (De, 2000). The bottles were kept air tight and labeled properly for identification and some parameters such as $\mathrm{pH}$, Electrical Conductivity (EC), Dissolved Oxygen (DO) and temperature of the samples were measured on the spot using glass electrode $\mathrm{pH}$ meter, EC meter,

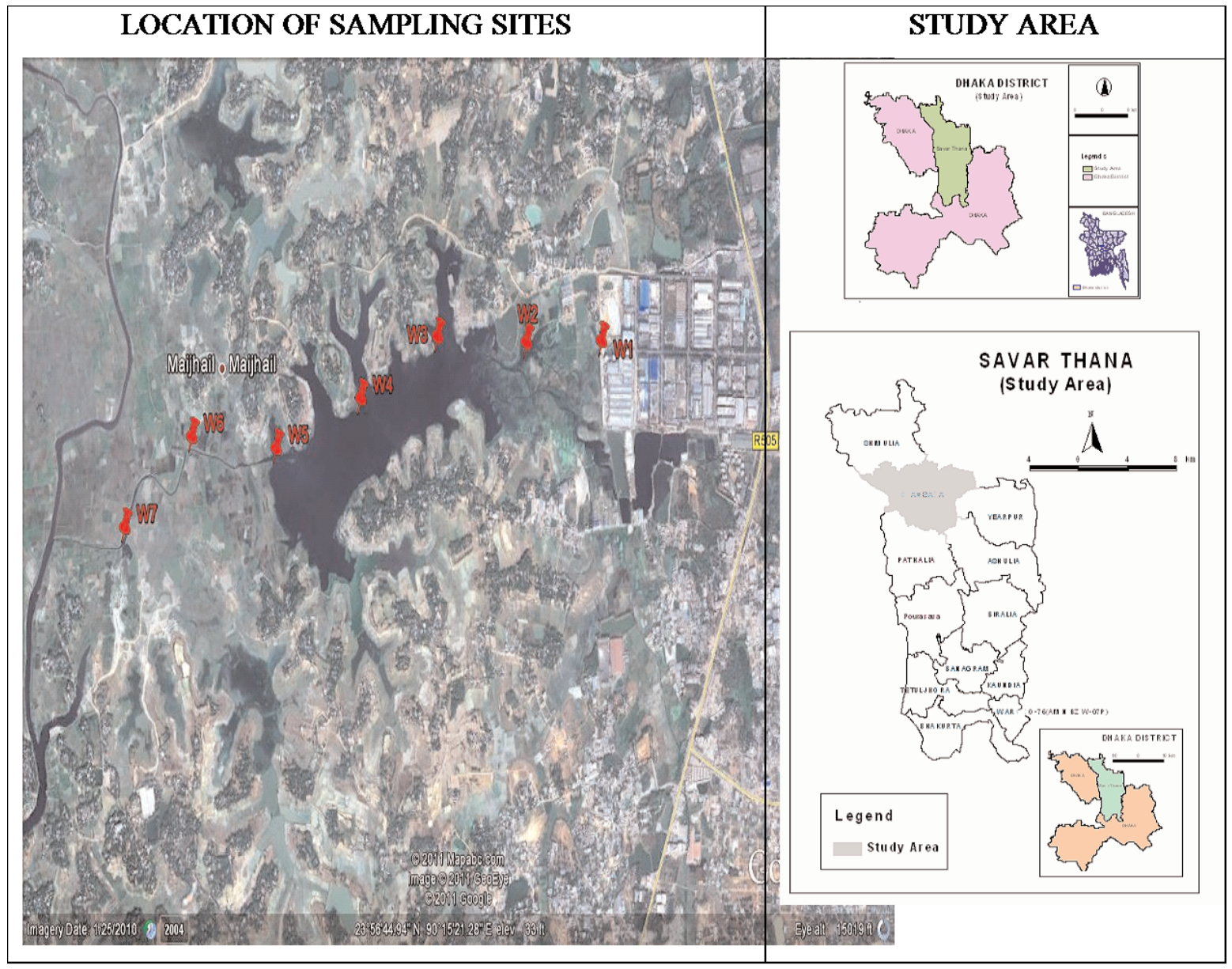

Fig. 1: Location of the study area and sampling sites 
DO meter and Thermometer respectively (Gupta, 2005, De, 2000 and Peavy et al., 1985). Aeration during sampling was avoided as much as possible. A portion of the water samples were acidified for metals analysis.

The physico-chemical analysis was carried out in the Analytical Research Division, BCSIR Laboratories, Dhaka. Physico-chemical parameters such as turbidity was measured by Turbidity meter (Hi C-114), total suspended solids (TSS) and total dissolved solids (TSS) were measured by gravimetric method (APHA, 1976), Biochemical oxygen demand $\left(\mathrm{BOD}_{5}\right)$, was measured by Winkler method (De, 2000) and salinity was measured by Portable Multiparameter Meter $\left({ }^{\mathrm{TM}} 156, \mathrm{HACH}\right)$.

First the samples were digested with nitric acid for heavy metal determination as described by Baker et al., (1982). Then the determination of metals like zinc $(\mathrm{Zn})$, copper $(\mathrm{Cu})$, nickel $(\mathrm{Ni})$, cadmium $(\mathrm{Cd})$, copper $(\mathrm{Cr})$, lead $(\mathrm{Pb})$, manganese $(\mathrm{Mn})$, calcium $(\mathrm{Ca})$ and magnesium $(\mathrm{Mg})$ of water samples were performed by Atomic Absorption Flame Emission Spectrophotometer (AA-6401F, SHIMADZU) and Fast Sequential Atomic Absorption Spectrometer (AA240FS, VARIAN). Sodium (Na) and potassium (K) were determined by Flame Photometer (JENWAY PFP 7).

A quantitative analysis of fluoride $\left(\mathrm{F}^{-}\right)$, chloride $\left(\mathrm{Cl}^{-}\right)$, nitrate $\left(\mathrm{NO}_{3}{ }^{-}\right)$, bromide $\left(\mathrm{Br}^{-}\right)$, phosphate $\left(\mathrm{PO}_{4}{ }^{3-}\right)$ and sulphate $\left(\mathrm{SO}_{4}{ }^{2-}\right)$ ) were determined by ion chromatograph (IC) (HIC10-A, SHIMADZU).

\section{Result and Discussion}

The average concentration of physico-chemical parameter of the wastewater of the study area and its comparison with the inland surface water standard value recommended by DOE (2003), Bangladesh is presented in Table I.

Highly colored liquid effluents with pungent odor were observed in the effluents of the study area.

Table I reveals that temperature range in the whole study area was $24^{\circ} \mathrm{C}$ to $57^{\circ} \mathrm{C}$ and in the point source $\left(\mathrm{W}_{1}\right)$ temperature was highest which begin to decline according to distance from the point source. Temperature in site $\mathrm{W}_{1}, \mathrm{~W}_{2}$ and $\mathrm{W}_{3}$ were $57{ }^{\circ} \mathrm{C}, 52{ }^{\circ} \mathrm{C}$ and $45{ }^{\circ} \mathrm{C}$ respectively which were higher than DOE standard. The average value of $\mathrm{pH}$ varied from 7.58 to 12.45 which exceeded the limit of DOE (6-9). The higher value of $\mathrm{pH}$ was measured in site $\mathrm{W}_{1}(12.45), \mathrm{W}_{2}$ (11.51), $\mathrm{W}_{3}(10.45)$ and $\mathrm{W}_{4}(9.47)$ which may be due to different kinds of dye stuff used in the dyeing process in different industries. In textile dyeing industries $\mathrm{H}_{2} \mathrm{O}_{2}$ and $\mathrm{NaOH}$ are used as bleaching and kier agents. Higher $\mathrm{pH}$ approaches in wastewater owing to the wastes composition of textile mills such as $\mathrm{NaOCl}, \mathrm{NaOH}, \mathrm{Na}_{2} \mathrm{SiO}_{3}$, surfactants and sodium phosphate (Sultana et al., 2009). Excessive pH is harmful for aquatic life like fish, microorganisms and aquatic plants. Water $\mathrm{pH}$ influences the other properties of waterbody, activity of organisms and potency of toxic substances present in the aquatic environment (Yusuff et al., 2005, Rouse, 1979).

The electric conductivity (EC) is usually used for indicating the total concentration of the ionized constituents of water. The average values of EC of the effluent varied from 2060 $\mu \mathrm{s} / \mathrm{cm}$ to $12400 \mu \mathrm{s} / \mathrm{cm}$ which indicates that a large amount of ionic substances was released from the textile industries like sodium, chloride etc. in the studied area. The average con-

Table I: Average concentration of physico-chemical properties of the study area and its comparison with the inland surface water standard value (DOE, 2003).

\begin{tabular}{lllllllll}
\hline Parameter & $\mathrm{W}_{1}$ & $\mathrm{~W}_{2}$ & $\mathrm{~W}_{3}$ & $\mathrm{~W}_{4}$ & $\mathrm{~W}_{5}$ & $\mathrm{~W}_{6}$ & $\mathrm{~W}_{7}$ & DOE $(2003)$ \\
\hline Temperature $\left({ }^{\circ} \mathrm{C}\right)$ & 57 & 52 & 45 & 37 & 32 & 28 & 24 & 40 \\
$\mathrm{pH}$ & 12.45 & 11.51 & 10.45 & 9.87 & 8.97 & 8.0 & 7.58 & $6-9$ \\
$\mathrm{EC}(\mu \mathrm{s} / \mathrm{cm})$ & 12400 & 11600 & 10100 & 8500 & 6300 & 3140 & 2060 & 1200 \\
$\mathrm{DO}(\mathrm{mg} / \mathrm{L})$ & 0.10 & 0.62 & 1.06 & 1.49 & 2.15 & 2.87 & 3.12 & $4.5-8$ \\
$\mathrm{BOD}(\mathrm{mg} / \mathrm{L})$ & 895 & 749 & 587 & 413 & 317 & 63.19 & 65.69 & 50 \\
$\mathrm{TSS}(\mathrm{mg} / \mathrm{L})$ & 2170 & 1937 & 1670 & 1548 & 1027 & 732 & 435 & 150 \\
TDS $(\mathrm{mg} / \mathrm{L})$ & 6840 & 6420 & 6150 & 4032 & 3147 & 2019 & 1036 & 2100 \\
Turbidity $(\mathrm{NTU})$ & 89.55 & 60.10 & 56.24 & 41.12 & 45.10 & 37 & 32.16 & ---- \\
Salinity $(\mathrm{ppt})$ & 7.1 & 6.6 & 6.3 & 4.6 & 3.1 & 2.4 & 1.0 & ---- \\
\hline
\end{tabular}


centration of EC in point source $\left(\mathrm{W}_{1}\right)$ was found to be 12400 $\mu \mathrm{s} / \mathrm{cm}$ which was around 10 times higher than the DOE standard (Table II). Such a high value of EC is not suitable for aquatic life and irrigation purposes.

DO in water is essential for aquatic life. Deficiency of DO in water gives rise to odoriferous products of anaerobic decomposition. The average value of DO of the study area varied from 0.10 to $3.12 \mathrm{mg} / \mathrm{L}$ which was much below the limit of DOE (4.5-8). (Table I). The content of DO in site $\mathrm{W}_{1}$ was very low $(0.10 \mathrm{mg} / \mathrm{l})$, which suggested that the industries were releasing lot of organic substances most likely the dyes that were high oxygen demanding wastes (Emongor et al., 2005). The presence of sufficient DO in water is a positive sign of a healthy body of water but the deficiencies of DO is a signal of severe pollution.

Biochemical oxygen demand (BOD) is the quantity of oxygen required by bacteria and other microorganisms during the biochemical degradation and transformation of organic matter present in wastewater under aerobic conditions (Dara, 2002). The average value of $\mathrm{BOD}_{5}$ of the study area varied from 63.19 to $895 \mathrm{mg} / \mathrm{L}$ which was higher than the limit of DOE $(50 \mathrm{mg} / \mathrm{L})\left(\right.$ Table I). The value of BOD5 in site $\mathrm{W}_{1}$, $\mathrm{W}_{2}$ and $\mathrm{W}_{3}$ was 895,749 and $587 \mathrm{mg} / \mathrm{L}$, respectively which was around 18, 15 and 12 times higher than that of $\mathrm{DOE}$ standard $(50 \mathrm{mg} / \mathrm{L})$. Such high value of $\mathrm{BOD}_{5}$ of wastewater of that area can cause serious damage to aquatic flora and fauna like fish and microorganisms (Kabir et al., 2002). $\mathrm{BOD}_{5}$ is an index of the biodegradable organics present. The industries in the DEPZ releases a lot of biochemical oxygen demanding wastes. Biochemical oxygen demanding wastes consume the dissolved oxygen from water. So this high value of $\mathrm{BOD}_{5}$ indicates the status of oxygen deficiency in water body. If large quantity of organic waste is present in the water supply, a lot of oxygen will be consumed by bacteria to decompose this waste. In this case, the demand for oxygen will be high; so the $\mathrm{BOD}_{5}$ level will be high. As the waste is consumed or dispersed through the water, $\mathrm{BOD}_{5}$ level will begin to decline (Vesilind et al., 1990). Table I also reveals that the $\mathrm{BOD}_{5}$ level begin to decline from the point source to the remote area.

Total suspended solid (TSS) values of the study area ranged from 435 to $2170 \mathrm{mg} / \mathrm{L}$. Highest value of TSS was observed in point source $(2170 \mathrm{mg} / \mathrm{L})$ which was about 14 times high- er than DOE standard $(150 \mathrm{mg} / \mathrm{L})$. TSS values of the study area begin to decline from point source as the waste disperses through the nearby waterbodies (Table I). TSS denotes the suspended impurities present in water. High TSS present in water bodies may block the sunlight required to photosynthesis by the bottom vegetation (Peavy et al., 1985; Davis and Cornwell, 1998). Total dissolved solid (TDS) of site $\mathrm{W}_{1}$, $\mathrm{W}_{2}$ and $\mathrm{W}_{3}$ was 6840,6420 and $6150 \mathrm{mg} / \mathrm{L}$, respectively which was around 3 times higher than the DOE standard $(2100 \mathrm{mg} / \mathrm{L})$ and extremely higher than the standard limit $250 \mathrm{mg} / \mathrm{L}$ (Peavy et al., 1985; Davis and Cornwell, 1998). The high amount of dissolved solids in water increases the water density; it influences osmoregulation of freshwater organisms and reduces solubility of gases. Increased $\mathrm{pH}$ value of the sample might have resulted in the dissolution of low molecular mass organic bases originating from dye industries. This also gives rise to higher TDS value (Moore et al., 1960). As the value of $\mathrm{pH}$ of the study area was high, the value of TDS was also high (Table I)

Turbidity in water is caused by suspended and colloidal matter such as clay, silt, finely divided organic and inorganic matter, and plankton and other microscopic organisms. The turbidity of the study area ranged between 32.16 to 89.55 NTU and it was highest in the point source. The value of Turbidity and salinity decreased with increasing the distance from point source.

In the study area, Fe content varied from 0.443 to 1.331 $\mathrm{mg} / \mathrm{L}$ which was within the limit of DOE (2003). The concentration of $\mathrm{Cu}, \mathrm{Ni}, \mathrm{Pb}$ and $\mathrm{Mn}$ of the study area were also within the limit of DOE (2003). It suggested that the textile dyeing industries of the study area use organic dyes instead of heavy metal pigment dyes. In site $\mathrm{W}_{1}$ and $\mathrm{W}_{2}$ the content of Cr was 0.615 and $0.571 \mathrm{mg} / \mathrm{L}$ which exceeded the limit of DOE (2003) (Table II).

Table II shows that the content of $\mathrm{Cr}$ gradually decreasing from the point source to the remote area. This result suggested that textile dyeing industries use chromium containing compounds such as chrome agent in dyeing processes. $\mathrm{Zn}$ content of the study area ranged from 0.308 to $0.134 \mathrm{mg} / \mathrm{L}$ which was within the limit of DOE (2003). The content of $\mathrm{Zn}$ was highest in site $\mathrm{W}_{1}(0.308 \mathrm{mg} / \mathrm{L})$ and lowest in $\mathrm{W}_{6}$ $0.134(\mathrm{mg} / \mathrm{L})$. The concentration of $\mathrm{Zn}$ decreased with increasing distance from source. The increase in nutrients of 
Table II: Comparison of the concentration of some metals of the study area with inland surface water standard value (DOE, 2003).

\begin{tabular}{lcccccccl}
\hline Parameter & $\begin{array}{c}\mathrm{W}_{1} \\
(\mathrm{mg} / \mathrm{L})\end{array}$ & $\begin{array}{c}\mathrm{W}_{2} \\
(\mathrm{mg} / \mathrm{L})\end{array}$ & $\begin{array}{c}\mathrm{W}_{3} \\
(\mathrm{mg} / \mathrm{L})\end{array}$ & $\begin{array}{c}\mathrm{W}_{4} \\
(\mathrm{mg} / \mathrm{L})\end{array}$ & $\begin{array}{c}\mathrm{W}_{5} \\
(\mathrm{mg} / \mathrm{L})\end{array}$ & $\begin{array}{c}\mathrm{W}_{6} \\
(\mathrm{mg} / \mathrm{L})\end{array}$ & $\begin{array}{c}\mathrm{W}_{7} \\
(\mathrm{mg} / \mathrm{L})\end{array}$ & DOE $(2003)$ \\
\hline $\mathrm{Fe}$ & 1.331 & 0.964 & 0.945 & 0.903 & 0.875 & 0.821 & 0.443 & 2.00 \\
$\mathrm{Zn}$ & 0.308 & 0.275 & 0.144 & 0.141 & 0.184 & 0.134 & 0.136 & 5.00 \\
$\mathrm{Cu}$ & 0.244 & 0.226 & 0.180 & 0.156 & 0.147 & 0.133 & 0.127 & 0.5 \\
$\mathrm{Ni}$ & 0.009 & 0.009 & 0.012 & 0.019 & 0.008 & 0.010 & 0.064 & 1.00 \\
$\mathrm{Cd}$ & $<0.01$ & $<0.01$ & $<0.01$ & $<0.01$ & $<0.01$ & $<0.01$ & $<0.01$ & 0.05 \\
$\mathrm{Cr}$ & 0.615 & 0.571 & 0.381 & 0.312 & 0.276 & 0.064 & 0.055 & 0.5 \\
$\mathrm{~Pb}$ & $<0.01$ & $<0.01$ & $<0.01$ & 0.03 & $<0.01$ & 0.02 & $<0.01$ & 0.1 \\
$\mathrm{Mn}$ & 0.089 & 0.087 & 0.093 & 0.085 & 0.078 & 0.081 & 0.079 & 5.00 \\
$\mathrm{Na}$ & 1580 & 1150 & 1680 & 1960 & 1250 & 1570 & 1460 & --- \\
$\mathrm{K}$ & 46.42 & 17.22 & 36.50 & 42.30 & 25.70 & 35.53 & 27.45 & ---- \\
$\mathrm{Ca}$ & 2.41 & 2.63 & 3.89 & 2.32 & 3.12 & 2.85 & 4.15 & ---- \\
$\mathrm{Mg}$ & 5.68 & 7.36 & 5.43 & 6.42 & 7.35 & 6.24 & 7.56 & ---- \\
\hline
\end{tabular}

water can cause spurt in algal productivity i.e., eutrophication. Bird droppings, natural run-off, fall of leaves and twigs from surrounding vegetation, continuous discharge of domestic waste, bathing, washing are principal sources of $\mathrm{N}$, $\mathrm{P}, \mathrm{K}$ in the wastewater of the study area. In the study area $\mathrm{Na}$, $\mathrm{K}, \mathrm{Ca}$ and $\mathrm{Mg}$ content of the water sample of the study area are shown in Table II which can be used as a benchmark for inland surface water of Industrial sites.

The F- concentration of the surface water in most of the studied industrial area are varied from 4.56 to $5.74 \mathrm{mg} / \mathrm{L}$ which was 4-6 times higher than the value of DOE (2003). The $\mathrm{Cl}^{-}$ concentrations was much lower than the DOE standard. All the chloride $\left(\mathrm{Cl}^{-}\right)$values were within the permissible limits of $200 \mathrm{mg} / \mathrm{L}$ (Gupta, 2005). The average $\mathrm{NO}_{3}{ }^{-}$concentration in the water samples of the study area ranged from 2.86 to $5.65 \mathrm{mg} / \mathrm{L}$ (Table III). In site $\mathrm{W}_{6}$ and $\mathrm{W}_{7}$ the value of $\mathrm{NO}_{3}{ }^{-}$ concentration was 5.65 and $5.15 \mathrm{mg} / \mathrm{l}$, respectively which were slightly higher than the limit of $5 \mathrm{mg} / \mathrm{L}$ (UCCC, 1974) that may be due to continuous discharge of combined industrial waste. In the other sites $\mathrm{NO}_{3}{ }^{-}$concentration was within the limit. The bromide concentration of the study area was not observable. The average phosphate content of the study area ranged from 4.16 to $6.56(\mathrm{mg} / \mathrm{L})$, these high levels of phosphate may originate from municipal wastewater discharges from nearby locality. The safe limit for sulphate $\left(\mathrm{SO}_{4}{ }^{2-}\right)$ concentration in all purposes is less than $<200 \mathrm{mg} / \mathrm{L}$ (WHO, 1998). Site $\mathrm{W}_{1}$ had the highest concentration of sulfate $(24.10 \mathrm{mg} / \mathrm{L})$ because of direct discharge of industrial waste.

\section{Correlation between physicochemical properties}

The correlation between physicochemical properties of water is shown in Table IV.

Table III: Anions concentration of water samples of the study area

\begin{tabular}{lcccccccc}
\hline Parameter & $\begin{array}{c}\mathrm{W}_{1} \\
(\mathrm{mg} / \mathrm{L})\end{array}$ & $\begin{array}{c}\mathrm{W}_{2} \\
(\mathrm{mg} / \mathrm{L})\end{array}$ & $\begin{array}{c}\mathrm{W}_{3} \\
(\mathrm{mg} / \mathrm{L})\end{array}$ & $\begin{array}{c}\mathrm{W}_{4} \\
(\mathrm{mg} / \mathrm{L})\end{array}$ & $\begin{array}{c}\mathrm{W}_{5} \\
(\mathrm{mg} / \mathrm{L})\end{array}$ & $\begin{array}{c}\mathrm{W}_{6} \\
(\mathrm{mg} / \mathrm{L})\end{array}$ & $\begin{array}{c}\mathrm{W}_{7} \\
(\mathrm{mg} / \mathrm{L})\end{array}$ & $\begin{array}{c}\mathrm{DOE} \\
(2003)\end{array}$ \\
\hline $\mathrm{F}^{-}$ & 5.53 & 5.74 & 4.75 & 5.23 & 4.56 & 0.25 & 5.67 & 1.00 \\
$\mathrm{Cl}^{-}$ & 27.32 & 28.30 & 16.76 & 25.52 & 28.39 & 24.76 & 26.95 & $150-600$ \\
$\mathrm{NO}_{2}{ }^{-}$ & $<0.01$ & $<0.01$ & $<0.01$ & $<0.01$ & $<0.01$ & $<0.01$ & $<0.01$ & $<1.00$ \\
$\mathrm{NO}_{3}{ }^{-}$ & 4.85 & 2.86 & 3.13 & 2.97 & 4.87 & 5.65 & 5.15 & 10 \\
$\mathrm{Br}^{-}$ & $<0.01$ & $<0.01$ & $<0.01$ & $<0.01$ & $<0.01$ & $<0.01$ & $<0.01$ & -- \\
$\mathrm{PO}_{4}{ }^{3-}$ & 6.56 & 5.39 & 4.16 & 5.35 & 6.24 & 5.98 & 6.15 & 6.00 \\
$\mathrm{SO}_{4}{ }^{2-}$ & 24.10 & 5.86 & 21.52 & 14.10 & 10.58 & 7.23 & 5.86 & --- \\
\hline
\end{tabular}


Table IV: Correlation between physiochemical properties of the water samples

\begin{tabular}{|c|c|c|c|c|c|c|c|c|}
\hline Parameters & $\mathrm{pH}$ & $\mathrm{EC}$ & DO & BOD & TSS & TDS & Turbidity & Salinity \\
\hline $\mathrm{pH}$ & 1 & & & & & & & \\
\hline $\mathrm{EC}$ & $0.980 * *$ & 1 & & & & & & \\
\hline DO & $-0.995 * *$ & $-0.993 * *$ & 1 & & & & & \\
\hline BOD & $0.994 * *$ & $0.981 * *$ & $-0.992 * *$ & 1 & & & & \\
\hline TSS & $0.985^{* *}$ & $0.992 * *$ & $-0.994 * *$ & $0.974 * *$ & 1 & & & \\
\hline TDS & $0.968^{* *}$ & $0.984 * *$ & $-0.981 * *$ & $0.973 * *$ & $0.975^{* *}$ & 1 & & \\
\hline Turbidity & $0.918^{* *}$ & $0.844^{*}$ & $-0.891 *$ & $0.914 * *$ & $0.857^{*}$ & $0.857^{*}$ & 1 & \\
\hline Salinity & $0.967^{* *}$ & $0.984 * *$ & $-0.981 * *$ & $0.963^{* *}$ & $0.985^{* *}$ & $0.995^{* *}$ & $0.844^{*}$ & 1 \\
\hline
\end{tabular}

$* *=0.01$ level of significance, $*=0.05$ level of significance

Table V: Correlation between metals of the collected water samples

\begin{tabular}{|c|c|c|c|c|c|c|c|c|c|c|}
\hline Parameters & $\mathrm{Fe}$ & $\mathrm{Zn}$ & $\mathrm{Cu}$ & $\mathrm{Ni}$ & $\mathrm{Cr}$ & $\mathrm{Mn}$ & $\mathrm{Na}$ & $\mathrm{K}$ & $\mathrm{Ca}$ & $\mathrm{Mg}$ \\
\hline $\mathrm{Fe}$ & 1 & & & & & & & & & \\
\hline $\mathrm{Zn}$ & $0.732 *$ & 1 & & & & & & & & \\
\hline $\mathrm{Cu}$ & $0.825^{*}$ & $0.914 * *$ & 1 & & & & & & & \\
\hline $\mathrm{Ni}$ & $-0.782 *$ & -0.403 & -0.486 & 1 & & & & & & \\
\hline $\mathrm{Cr}$ & $0.837^{*}$ & $0.859^{*}$ & $0.964 * *$ & -0.559 & 1 & & & & & \\
\hline $\mathrm{Mn}$ & 0.628 & 0.356 & $0.700^{*}$ & -0.406 & 0.698 & 1 & & & & \\
\hline $\mathrm{Na}$ & 0.096 & -0.434 & -0.187 & 0.054 & -0.151 & 0.315 & 1 & & & \\
\hline $\mathrm{K}$ & 0.471 & -0.039 & 0.117 & -0.156 & 0.095 & 0.369 & $0.833^{*}$ & 1 & & \\
\hline $\mathrm{Ca}$ & -0.674 & -0.520 & -0.476 & 0.632 & -0.507 & -0.124 & -0.141 & -0.296 & 1 & \\
\hline $\mathrm{Mg}$ & -0.617 & -0.047 & -0.336 & 0.457 & -0.303 & $-0.741^{*}$ & -0.631 & $-0.798^{*}$ & 0.162 & 1 \\
\hline
\end{tabular}

$* *=0.01$ level of significance, $*=0.05$ level of significance

The coefficient of correlation analysis amo ng physicochemical properties (Table IV) indicated that all the parameters had significant positive or negative contribution to pollute the water. The correlation between DO and $\mathrm{pH}$ was strongly negative. The correlation coefficient $(\mathrm{r}=-0.995 * *)$ showed that the value of $\mathrm{pH}$ was inversely proportional to the DO. On the contrary, the coefficient of correlation analysis among cations (Table V) indicated that Fe showed positive significant correlation with $\mathrm{Zn}, \mathrm{Cu}$ and $\mathrm{Cr}$ and significant negative correlation with $\mathrm{Ni}$ in case of water quality deterioration. $\mathrm{Cu}$ and $\mathrm{Cr}$ showed significant positive correlation with $\mathrm{Zn}$. Table $\mathrm{V}$ also shows that $\mathrm{Mg}$ content was inversely proportional to the value of $\mathrm{Mn}$ and $\mathrm{K}$. So content of metal in industrial wastewater have significant contribution to pollute the waterbody. The correlation among anions (Table VI) shows that there was a significant positive interaction of $\mathrm{PO}_{4}{ }^{3-}$ with $\mathrm{Cl}^{-}$and $\mathrm{NO}_{3}{ }^{-}$.

Table VI: Correlation between anions of the water samples

\begin{tabular}{llllll}
\hline & $\mathrm{F}^{-}$ & $\mathrm{Cl}^{-}$ & $\mathrm{NO}_{3}{ }^{-}$ & $\mathrm{PO}_{4}{ }^{3-}$ & $\mathrm{SO}_{4}{ }^{2-}$ \\
\hline $\mathrm{F}^{-}$ & 1 & & & & \\
$\mathrm{Cl}^{-}$ & 0.174 & 1 & & & \\
$\mathrm{NO}_{3}{ }^{-}$ & -0.522 & 0.314 & 1 & & \\
$\mathrm{PO}_{4}{ }^{3-}$ & -0.082 & $0.824^{*}$ & $0.745^{*}$ & 1 & \\
$\mathrm{SO}_{4}{ }^{2-}$ & 0.247 & -0.479 & -0.196 & -0.218 & 1 \\
\hline
\end{tabular}

$*=0.05$ level of significance 


\section{Conclusion}

Industrial sector in Bangladesh release huge amount of effluent to aquatic systems, which contain toxic and hazardous pollutants degrading the environment. DEPZ is one of the prominent industrial sectors with more than $80 \%$ industries without proper effluent treatment plant severely affects surface water quality of the surrounding area. The reported $\mathrm{pH}$, EC, BOD, TSS, TDS, Turbidity and Salinity were quite higher than the recommended values of DOE in point source and nearby waterbody. DO value also much lower than the limit of DOE. Aquatic life hardly survives in such type of condition. Although the content of metals like $\mathrm{Fe}, \mathrm{Cu}, \mathrm{Ni}$, $\mathrm{Pb}, \mathrm{Mn}$ and $\mathrm{Zn}$ were within the permissible limit, the content of $\mathrm{Cr}$ exceeded the limit of DOE near industrial site. Some anionic pollutants also impart negative impacts on waterbody. Further more, there is a significant correlation between water parameters to pollute the water. So the present study shows that the surface water gets contaminated and polluted due to organic and metal pigment dyes, inorganic matter, bleaching and kier agents and surfactants etc. used by the various industries of the study area. If the present scale of industrial pollution goes on without taking proper treatment action, the water quality will turn into a toxic and poisonous in the long run. So it is urgently needed to take proper action in preventing pollution of the area.

\section{References}

APHA (1976). Standard methods for the examination of water and wastewater (14th ed). American Public Health Association, Washington. 1193.

Baker D, Amacher E and Michael C (1982). Methods of soil analysis, part 2. American Society of Agronomy, Inc. Madison, Wisconsin. pp. 323-336.

Chindah AC, Braide AS and Sibeudu OC (2004). Distributions of hydrocarbons and heavy metals in sediments and a crustacean (shrimps- Penaeus notialis) from the bonny/ new calabar river estuary, Niger Delta. Ajeam-Ragee, 9, pp 1-14.

Dara SS (2002). A Textbook of Environmental Chemistry and Pollution Control. S. Chand and Company Limited, New Delhi, India. pp 24-30.
Davis ML and Cornwell DA (1998). Introduction to Environmental Engineering. WCB/McGraw-Hill Book Co., Singapore. pp 469-535.

De A K (2000). Environmental Chemistry. 4th Ed. New Age International P. limited, New Delhi. pp 2-4, 269.

DOE (Department of Environment). (2003). A Compilation of Environmental Laws of Bangladesh. pp 212-214.

Emongor V, Kealotswe E, Koorapetse I, Sarihvasa S and Keikanetswe S (2005). Pollution indicators in Gaberone effluent; J. Appl. Sci., 5: 147-150.

Gupta PK (2005). Methods in Environmental Analysis: water, soil and air. Agrobios Jodhpur, India. pp 13-73.

Haque S, Yasmin H and Rahman M.H. (2002). Environmental pollution in Bangladesh, Earth Community Organization (ECO). pp 38-47.

Islam MS, Mahmud MS, Chowdhury N and Shamsad SZKM (2009). Water and sediment anality of Fay's Lake, Chittagong; Dhaka Univ. J. Bio. Sci. 18 (2):147158.

Kabir SE, Kabir M, Mia CM, Begum N, Chowdhury D, Sultana MS and Rahman MS (2002). Assessment of Effluent Quality of Dhaka Export Processing Zone with special Emphasis to that of the Textile and Dyeing Industries; Jahangirnag. Univer. J. of Scien. 25: $137-$ 145 .

Moore M, McLeod K and Reed D (1960). Fisheries: Conservation, propagation and regulation, Washington Department of Fisheries, USA. pp. 155-163.

Nemerow NL (1978). Indutrial Water Pollution: origins, characteristics and Treatment. Addison Wesley, Reading, Massachusetts. p 738

Peavy HS, Rowe DRR and Tehobanoglous G (1985). Environmental Engineering. McGraw-Hill Book Company, NY, USA. pp 417-461.

Rouse RD (1979). Water quality management in pond fish culture. In: Research and Development Series No. 22, Project: AID/DSAN-G 0039, Auburn University, Alabama, USA. 
Sultana MS, Islam MS, Saha R and Mansur MA (2009). Impact of the Effluents of Textile Dyeing Industries on the Surface Water Quality inside D.N.D Embankment, Narayanganj; Bangladesh J. Sci. Ind. Res., 44(1): 6580.

UCCC (1974). Guidelines for interpretations of Water Quality for Irrigation. Technical Bulletin, University of California Committee of Consultants, Cafornia, USA. pp. 20-28.

Vesilind PA, Peirce JJ and Weiner RF (1990). Environmental Pollution and Control, Butterworth-Heinermann, Boston-London-Sydney-Toronto-Wellington. p 389.
WHO (1998). Guidelines for drinking-water quality and recommendations. 2nd Ed. World Health Organization, Geneva, Vol-1.

Yusuff RO, Sonibare JA (2005). Characterization of textile industrial effluents in Kaduna, Nigeria and pollution implications. Global Nest: the Int. J. 6 (3):212-221

Received : 14 June 2011; Revised : 22 November 2011; Accepted : 17 May 2012. 